\title{
Pendidikan Kesehatan Secara Virtual: Efektifkah Sebagai Upaya Pencegahan Terjadinya Penundaan Dalam Mengakses Pelayanan Kesehatan Ketika Mengalami Sindrom Koroner Akut
}

\author{
Jeki Refialdinata*, Mandria Yundelfa \\ Politeknik 'Aisyiyah Sumatera Barat \\ *Correspondence email: jekirefialdinata@gmail.com, mandriayundelfa@gmail.com
}

\begin{abstract}
Abstrak. Sindrom Koroner Akut (SKA) merupakan penyebab utama terjadinya kematian mendadak pada seseorang. Kematian mendadak akibat SKA dapat dicegah jika individu yang menunjukkan gejala SKA segera memperoleh pelayanan kesehatan. Ketika keluarga (caregiver) memiliki pengetahuan yang baik tentang SKA maka keterlambatan tersebut dapat dihindari. Metode pelaksanaan pendidikan kesehatan yang aman digunakan di masa pandemi covid-19 yaitu dilaksanakan secara virtual. Tujuan penelitian ini adalah untuk mengkaji keefektifan pendidikan kesehatan secara virtual dalam meningkatkan pengetahuan keluarga mengenai SKA. Penelitian dilaksanakan di wilayah kerja Puskesmas Andalas Kota Padang. Jenis penelitian yang digunakan adalah kuantitatif menggunakan desain quasy eksperiment non equivalent control group design. Sampel pada penelitian ini adalah anggota keluarga dari individu yang berisiko tinggi mengalami SKA berjumlah 266 orang terdiri atas 133 orang yang berada pada kelompok kasus dan 133 orang lainnya pada kelompok kontrol. Sampel dipilih menggunakan teknik purposive sampling. Pemahaman responden atas materi setelah pendidikan kesehatan baik pada kelompok kasus maupun kelompok kontrol, dievaluasi menggunakan instrumen berupa kuesioner yang terdiri dari 15 pertanyaan. Data yang diperoleh dari hasil kuesioner dianalisis secara statistik menggunakan program SPSS. Hasil penelitian menunjukkan bahwa pendidikan kesehatan secara virtual memiliki pengaruh positif terhadap pengetahuan responden tentang SKA pada kelompok kasus dibandingkan kelompok kontrol. Hasil penelitian menunjukkan terdapat pengaruh yang bermakna pendidikan kesehatan terhadap pengetahuan $(\mathrm{p}$ value $=0,000)$ responden pada kelompok kasus. Namun tidak terdapat pengaruh pada kelompok kontrol ( $p$ value 0,181 ). Tim promosi kesehatan hendaknya tetap memberikan pendidikan kesehatan ke masyarakat tentang SKA di masa pandemi covid-19 secara virtual. Dengan demikian, program promosi kesehatan dapat terus terlaksana tanpa harus mengkhawatirkan adanya penyebaran virus corona.
\end{abstract}

Kata kunci: Pendidikan kesehatan virtual; upaya pencegahan terjadinya penundaan; sindrom koroner akut

Abstract. Acute Coronary Syndrome (ACS) is the main cause of sudden death in a person. Sudden death due to ACS can be prevented if individuals who show symptoms of ACS immediately obtain health services. If the family (caregiver) has good knowledge about ACS, the delay can be avoided. The method of implementing health education that is safe to use during the COVID-19 pandemic is to be carried out virtually. The purpose of this study was to examine the effectiveness of virtual health education in increasing family knowledge about ACS. The research was carried out in the work area of the Andalas Public Health Center, Padang City. The type of research used is quantitative using a quasi-experimental non-equivalent control group design. The sample in this study were family members of individuals who are at high risk of experiencing ACS totaling 266 people consisting of 133 people in the case group and 133 others in the control group. The sample was selected using purposive sampling technique. Respondents' understanding of the material after health education, both in the case group and the control group, was evaluated using an instrument in the form of a questionnaire consisting of 15 questions. The data obtained from the questionnaire were analyzed statistically using the SPSS program. The results showed that virtual health education had a positive effect on respondents' knowledge of ACS in the case group compared to the control group. The results showed that there was a significant effect of health education on knowledge ( $p$ value $=0.000$ ) of respondents in the case group. However, there was no effect in the control group ( $p$ value 0,181). The health promotion team should continue to provide health education to the public about ACS during COVID-19 pandemic using virtual media. Thus, health promotion programs can continue to be carried out without having to worry about the spread of the corona virus.

Keywords: Virtual health education; efforts to prevent delays; acute coronary syndrome

\section{PENDAHULUAN}

Sindrom Koroner Akut (SKA) atau biasa dikenal dengan Penyakit Jantung Koroner (PJK) merupakan penyebab utama terjadinya kematian mendadak pada seseorang. Berdasarkan hasil survei nasional tahun 2013 terdapat 883.447 orang yang menderita SKA, dengan prevalensi di Provinsi Sumatera Barat sebesar 0,6\% diatas angka nasional yakni $0,5 \%$, dan kondisi ini akan terus meningkat pada tahun 2030 (Kemenkes RI, 2014). Di Kota Padang, berdasarkan data dari Dinas Kesehatan tahun 2016 terdapat 22,69\% warga Kota Padang yang mengalami PJK dengan kejadian di Wilayah Kerja Puskesmas Andalas pada tahun 2018 sebesar 76 kasus (Laporan Tahunan Puskesmas Andalas, 2019).

Kematian mendadak akibat SKA dapat dicegah jika individu yang dicurigai mengalami SKA segera memperoleh pelayanan Kesehatan (Amsterdam et al., 2014). Namun, dalam konteks hubungan antara pasien dan pelayanan kesehatan, keterlambatan (delay) menjadi penyebab utama ketidakberhasilan pengobatan. Individu 
Jeki Refialdinata dan Mandria Yundelfa, Pendidikan Kesehatan Secara Virtual: Efektifkah Sebagai Upaya Pencegahan Terjadinya Penundaan Dalam Mengakses Pelayanan Kesehatan Ketika Mengalami Sindrom Koroner Akut

sampai dipelayanan kesehatan dalam keadaan telah meninggal dunia (Joob \& Wiwanitkit, 2013). Mayoritas keterlambatan tersebut terjadi karena kurangnya pengetahuan keluarga mengenai SKA dan adanya kesalahan dalam memilih pelayanan kesehatan yang tepat untuk mengatasi SKA (Koc et al., 2017; Wechkunanukul et al., 2016). Hal ini sejalan dengan temuan peneliti pada penelitian sebelumnya, responden dalam hal ini keluarga gagal dalam mengenali gejala pada saat pasien mengalami serangan SKA (Refialdinata et al, 2018).

Serangan SKA tidak dapat diprediksi waktu kejadiannya. Ketika seseorang mengalami SKA, maka keluarga yang memiliki peran membuat keputusan tentang jenis pertolongan yang tepat bagi pasien (Aziz et al., 2018). Berdasarkan hal itu, salah satu upaya yang dapat dilakukan untuk memberikan pemahaman keluarga mengenai SKA ialah pendidikan kesehatan. Pendidikan kesehatan dapat dilaksanakan dengan menggunakan metode seperti ceramah, diskusi kelompok, dan seminar yang dikombinasikan dengan penggunaan media seperti slide powe point, leaflet, video atau booklet (Nurmala et al., 2018; Induniasih \& Ratna, 2015). Namun, mengingat masih adanya pandemi covid-19 maka metode yang aman digunakan ialah metode yang dapat menjamin tidak adanya kerumunan masyarakat ketika pendidikan kesehatan dilaksanakan. Adapun metode pendukung yang memenuhi syarat tersebut ialah dengan memanfaatkan jaringan internet (virtual).

Survei awal yang peneliti lakukan dengan wawancarai petugas Puskesmas Andalas Kota Padang didapatkan data bahwa semenjak pandemi covid-19 Puskesmas tidak lagi melakukan kegiatan promosi kesehatan dalam bentuk ceramah ke masyarakat yang berkunjung ke Puskesmas. Hal ini dilakukan untuk menghindari kerumunan, ungkap petugas Puskesmas. Berdasarkan hal tersebut, maka perlu dilakukan penelitian mengenai keefektifan pendidikan kesehatan secara virtual dalam meningkatkan pengetahuan keluarga mengenai SKA.

\section{METODE}

Penelitian yang dilaksanakan merupakan penelitian quasi eksperimen non equivalent control group design, untuk membuktikan pengaruh pendidikan kesehatan secara virtual tentang SKA terhadap pengetahuan keluarga dalam upaya pencegahan terjadinya penundaan dalam mengakses pelayanan kesehatan ketika serangan SKA. Penelitian ini dilaksanakan di wilayah kerja Puskesmas Andalas Kota Padang dari bulan Maret hingga November 2021. Sampel pada penelitian ini adalah 266 orang anggota keluarga (caregiver) dari individu berisiko SKA yang terdiri atas 133 orang kelompok kasus dan 133 orang kelompok kontrol. Responden dipilih dengan menggunakan teknik purposive sampling. Adapun kriteria inklusi dari sampel penelitian, yaitu: 1) Memiliki individu berisiko SKA: usia $>40$ tahun dengan obesitas (BMI >30), diabetes mellitus, atau hipertensi; 2) Usia 18-40 tahun; 3) Mampu membaca dan mengoperasikan smartphone; dan 4) Bersedia untuk terlibat dalam penelitian.

Metode Pendidikan kesehatan pada kelompok kasus yang digunakan adalah presentasi dengan slidepowerpoint melalui video conference menggunakan aplikasi zoommeeting. Intervensi berupa video conference dilakukan sebanyak 1 kali untuk setiap responden. Setelah pendidikan kesehatan dilaksanakan, responden yang berada pada kelompok kasus akan mendapatkan leaflet SKA. Sementara itu, responden yang berada pada kelompok kontrol hanya mendapatkan leaflet tentang SKA. Pemahaman responden atas materi baik pada kelompok kasus maupun kontrol, dievaluasi menggunakan instrumen berupa kuesioner tentang pengetahuan SKA yang telah dilakukan uji validitas dan reliabilitas. Pretest diberikan saat membuat kontrak dengan responden, sedangkan postest dilakukan 1 minggu setelah responden mendapat intervensi. Data yang diperoleh dari hasil kuesioner dianalisis secara statistik menggunakan program SPSS.

\section{HASIL DAN PEMBAHASAN}

Tabel 1 menunjukkan bahwa sebagian besar responden pada kelompok kasus adalah perempuan $(63,9 \%)$, rentang usia $18-29$ tahun $(75,9 \%)$, pendidikan terakhir perguruan tinggi $(54,9 \%)$, dan bekerja $(74,5 \%)$. Sedangkan pada kelompok kontrol sebagian besar adalah perempuan $(80,5 \%)$, berada pada rentang usia 18-29 tahun $(69,2 \%)$, pendidikan terakhir $\leq \operatorname{SMA}(52,6 \%)$, dan bekerja $(74,4 \%)$.

Tabel 2 menjelaskan bahwa berdasarkan analisis statistik didapatkan p-value $0,000 \quad(\mathrm{p}<0,05)$ pada kelompok kasus dan 0,181 ( $\mathrm{p}>0,05)$ pada kelompok kontrol. Ini berarti ada pengaruh pendidikan kesehatan secara virtual terhadap pengetahuan keluarga tentang SKA pada kelompok kasus.

Tabel 1. Distribusi Frekuensi Karakteristik Responden pada Kelompok Kasus dan Kelompok Kontrol

\begin{tabular}{llcccc}
\hline Karakteristik & \multirow{2}{*}{ Kespondegori } & \multicolumn{2}{c}{ Kasus } & \multicolumn{2}{c}{ Kontrol } \\
\cline { 3 - 6 } & & $\mathbf{N}$ & $\%$ & $\mathbf{n}$ & $\%$ \\
\hline Jenis kelamin & Laki-laki & 48 & 36,1 & 26 & 19,5 \\
& Perempuan & 85 & 63,9 & 107 & 80,5 \\
Umur & $18-29$ & 101 & 75,9 & 92 & 69,2 \\
\multirow{3}{*}{ Pendidikan } & $>29-40$ & 32 & 24,1 & 41 & 30,8 \\
& $\leq$ SMA & 60 & 45,1 & 70 & 52,6 \\
Pekerjaan & PT & 73 & 54,9 & 63 & 47,4 \\
& Bekerja & 99 & 74,5 & 89 & 74,4 \\
& Tidak Bekerja & 34 & 33,1 & 44 & 25,6 \\
\hline
\end{tabular}


Jeki Refialdinata dan Mandria Yundelfa, Pendidikan Kesehatan Secara Virtual: Efektifkah Sebagai Upaya Pencegahan Terjadinya Penundaan Dalam Mengakses Pelayanan Kesehatan Ketika Mengalami Sindrom Koroner Akut

Tabel 2. Pengaruh Pendidikan Kesehatan secara Virtual terhadap Pengetahuan Keluarga tentang SKA

\begin{tabular}{lrc}
\hline Pengetahuan & Mean & p value \\
\hline $\begin{array}{l}\text { Kelompok Kasus } \\
\text { Pretest }\end{array}$ & 8,21 & 0,000 \\
$\begin{array}{l}\text { Postest } \\
\text { Kelompok Kontrol }\end{array}$ & 13,38 & \\
Pretest & 7,38 & 0,181 \\
Postest & 7,36 & \\
\hline
\end{tabular}

\section{Pembahasan}

Berdasarkan hasil penelitian didapatkan perbedaan pengetahuan mengenai SKA antara kelompok kasus dan kelompok kontrol. Kelompok kasus diberikan intervensi berupa pendidikan kesehatan menggunakan video conference sementara kelompok kontrol hanya memperoleh materi pendidikan kesehatan tentang SKA melalui leaflet.

Hasil uji statistik menjelaskan bahwa pendidikan kesehatan secara virtual memiliki pengaruh positif terhadap pengetahuan keluarga tentang SKA di wilayah kerja Puskesmas Andalas Kota Padang. Temuan pada penelitian ini sesuai dengan penjelasan Ashraf et al., (2020) bahwa pendidikan kesehatan manggunakan video conference mampu meningkatkan pengetahuan partisipan tentang SKA di masa pandemi covid-19. Hal yang serupa juga dijelaskan oleh penelitian lainnya, terdapat peningkatan pengetahuan responden tentang materi kesehatan setelah diberikan pendidikan kesehatan melalui video conference (Calder, 2018; Kay \& Pasarica, 2019; Pencle et al., 2020).

Penggunaan video conference sebagai media pendidikan kesehatan yang diikuti dengan diskusi memungkinkan peningkatan interaksi antara pemberi materi dan peserta yang berada pada kelompok kasus. Hal ini memberi pengaruh yang positif terhadap pengetahuan peserta pendidikan kesehatan tentang SKA. Partisipan dapat bertanya langsung ke pemberi materi saat sesi diskusi tanpa harus bertemu tatap muka (Putranti et al., 2021). Diskusi mampu membuat informasi yang diterima oleh objek pendidikan kesehatan maksimal dan dapat bertahan untuk jangka waktu yang lama (Abdulbaki et al., 2018). Pengaruh positif terhadap pengetahuan partisipan pada kelompok kasus tidak dialami oleh partisipan pada kelompok kontrol. Peserta pada kelompok kontrol tidak mendapatkan penjelasan materi dan tidak memiliki kesempatan untuk diskusi, sehingga pengetahuan mereka tentang SKA tidak sebaik peserta kelompok kasus.

Pendidikan kesehatan merupakan proses pembelajaran dengan tujuan untuk meningkatkan pemahaman atau interpretasi individu terhadap kesehatan (Notoatmodjo, 2010). Interpretasi ini nantinya akan memberi pengaruh terhadap persepsi dan membantu dalam pengambilan keputusan yang selaras dengan tujuan kesehatan. Pelaksanaan pendidikan kesehatan pada penelitian ini bertujuan untuk membuat keluarga memiliki interpretasi yang baik tentang SKA sehingga menaruh perhatian terhadap ancaman SKA bagi individu yang berisiko.

Pengetahuan yang benar tentang SKA harus dimiliki oleh masayarakat. Pengetahuan dapat menjadi modal untuk menghadirkan kesadaran ke arah yang lebih baik. selanjutnya menjadi dasar dalam membuat keputusan dan berbuat. Ketika masyarakat telah memiliki pengetahuan yang baik tentang SKA, maka mortalitas SKA dapat diturunkan. Masyarakat tidak lagi kesulitan untuk menentukan atau memilih tindakan yang efektif di saat ada anggota masayarakat menunjukkan gejala SKA. Mereka hanya perlu mengingat kembali informasi yang pernah diperoleh sebelumnya tentang SKA.

Saat ini gaya hidup masyarakat tidak bisa dipisahkan dengan smartphone. Sebagian besar masyarakat dari usia remaja hingga dewasa telah memakai smartphone yang dapat dimasukkan aplikasi video conference. Kondisi ini memberi peluang dan kemudahan bagi tenaga kesehatan untuk memberikan edukasi secara virtual. Smartphone bisa dimanfaatkan sebagai sarana untuk meningkatkan kesehatan masyarakat di masa pandemi Covid-19 yang mengharuskan untuk meminimalkan kontak fisik dan tatap muka. Di tengah pandemi covid-19, tenaga kesehatan masih tetap bisa memberikan pendidikan kesehatan kepada masayarakat tentang SKA tanpa perlu khawatir timbulnya cluster baru penyebaran covid-19 yang biasa muncul karena adanya kerumunan. Melalui upaya ini diharapkan masyarakat senantiasa memiliki kesadaran yang baik terhadap ancaman SKA. Selanjutnya membuat keputusan yang dapat membuat individu dengan gejala SKA terhindar dari penundaan dalam memperoleh pertolongan dini pada fasilitas pelayanan kesehatan.

\section{SIMPULAN}

Pendidikan kesehatan secara virtual memiliki pengaruh terhadap pengetahuan keluarga tentang SKA di wilayah kerja Puskesmas Andalas kota Padang;

\section{Saran}

1. Tim promosi kesehatan hendaknya tetap memberikan pendidikan kesehatan ke masyarakat tentang SKA di masa pandemi covid-19 secara virtual.

2. Peneliti selanjutnya hendaknya mengkaji tentang perbedaan keefektifan dari setiap jenis aplikasi video conference terhadap pengetahuan keluarga tentang SKA.

\section{DAFTAR PUSTAKA}

Abdulbaki, K., Suhaimi, M., Alsaqqaf, A., \& Jawad, W. (2018). The Use of the Discussion Method at University: Enhancement of Teaching and 
Jeki Refialdinata dan Mandria Yundelfa, Pendidikan Kesehatan Secara Virtual: Efektifkah Sebagai Upaya Pencegahan Terjadinya Penundaan Dalam Mengakses Pelayanan Kesehatan Ketika Mengalami Sindrom Koroner Akut

Learning. International Journal of Higher Education, 7(6), 118-128.

Amsterdam, E.A., Wenger, N.K., Brindis, R.G., Casey, D.E., Ganiats, T.G., Holmes, D.R., et al. 2014. 2014 AHA/ACC guideline for the management of patients with non-st-elevation acute coronary syndromes: A report of the American college of cardiology/American heart association task force on practice guidelines, Circulation. 130(25): e344e426 doi: 10.1161/CIR. 0000000000000134.

Ashraf, S., Ilyas, S., \& Alraies, M. C. (2020). Acute coronary syndrome in the time of the COVID-19 pandemic. European Heart Journal, 41(22), 20892091.

Aziz, A.N., Kumboyono, K., Wihastuti, T.A., Rachmawati, S.D., and Refialdinata, J. 2018. The needs of families of the patients with acute coronary syndrome in emergency room of public health center, World Journal of Advance Healthcare Research. 2(4): 48-52.

Calder, S. (2018). Health System Learning Using Synchronous Video Conferencing Technology (Doctoral dissertation, Simmons College).

Induniasih \& Ratna, W. (2015). Promosi Kesehatan: Pendidikan Kesehatan dalam Keperawatan. Yogyakarta: Pustaka Baru Press.

Joob, B., and Wiwanitkit, V. 2013. Acute chest pain: What about the time before visiting to the physician?, Journal of Acute Disease. 2(4): 330331. doi: 10.1016/S2221-6189(13)60154-7.

Kay, D., \& Pasarica, M. (2019). Using technology to increase student (and faculty satisfaction with) engagement in medical education. Advances in physiology education, 43(3), 408-413.

Kementerian Kesehatan Republik Indonesia [Kemenkes RI]. 2014. Infodatin: Situasi kesehatan jantung. Pusat Data dan Informasi Kementerian Kesehatan RI. Jakarta. p. 2-8.

Koc, S., Durna, Z., and Akin, S. 2017. Interpretation of symptoms as a cause of delays in patients with acute myocardial infarction, Istanbul, Turkey, Eastern Mediterranean Health journal. 23(4): 287294.

Notoatmodjo, S. (2010). Promosi kesehatan, teori dan aplikasi (Revisi). Rineka Cipta

Nurmala, I. (2018). Promosi Kesehatan. Surabaya: Airlangga University Press.

Pencle, F. J., Benny, A., Quijada, K. A., Seale, J. A., \& Chin, K. R. (2018). Utility of mobile apps for video conferencing to follow patients at home after outpatient surgery. JAAOS Global Research \& Reviews, 2(12).

Putranti, D., Bhakti, C. P., Rahman, F. A., \& Kurniasih, C. (2021, March). Video Conference: Strategy Collaboration Counselor and Parents in New Normal Era. In BICED 2020: Proceedings of the 2nd EAI Bukittinggi International Conference on Education, BICED 2020, 14 September, 2020, Bukititinggi, West Sumatera, Indonesia (p. 114). European Alliance for Innovation.

Refialdinata, J., Kumboyono, K., Wihastuti, T.A., Rachmawati, S.D. \& Aziz, A.N. 2018. Acute coronary syndrome: are patients and family members aware of the symptoms of attack? Współczesne Pielęgniarstwo i Ochrona Zdrowia, 7(2): 31-34.

Wechkunanukul, K., Grantham, H., and Clark, R.A. 2016. Global review of delay time in seeking medical care for chest pain: An integrative literature review, Australian Critical Care: Official Journal of the Confederation of Australian Critical Care Nurses. 30(1): 13-20. doi: 10.1016/j.aucc. 2016.04.002 